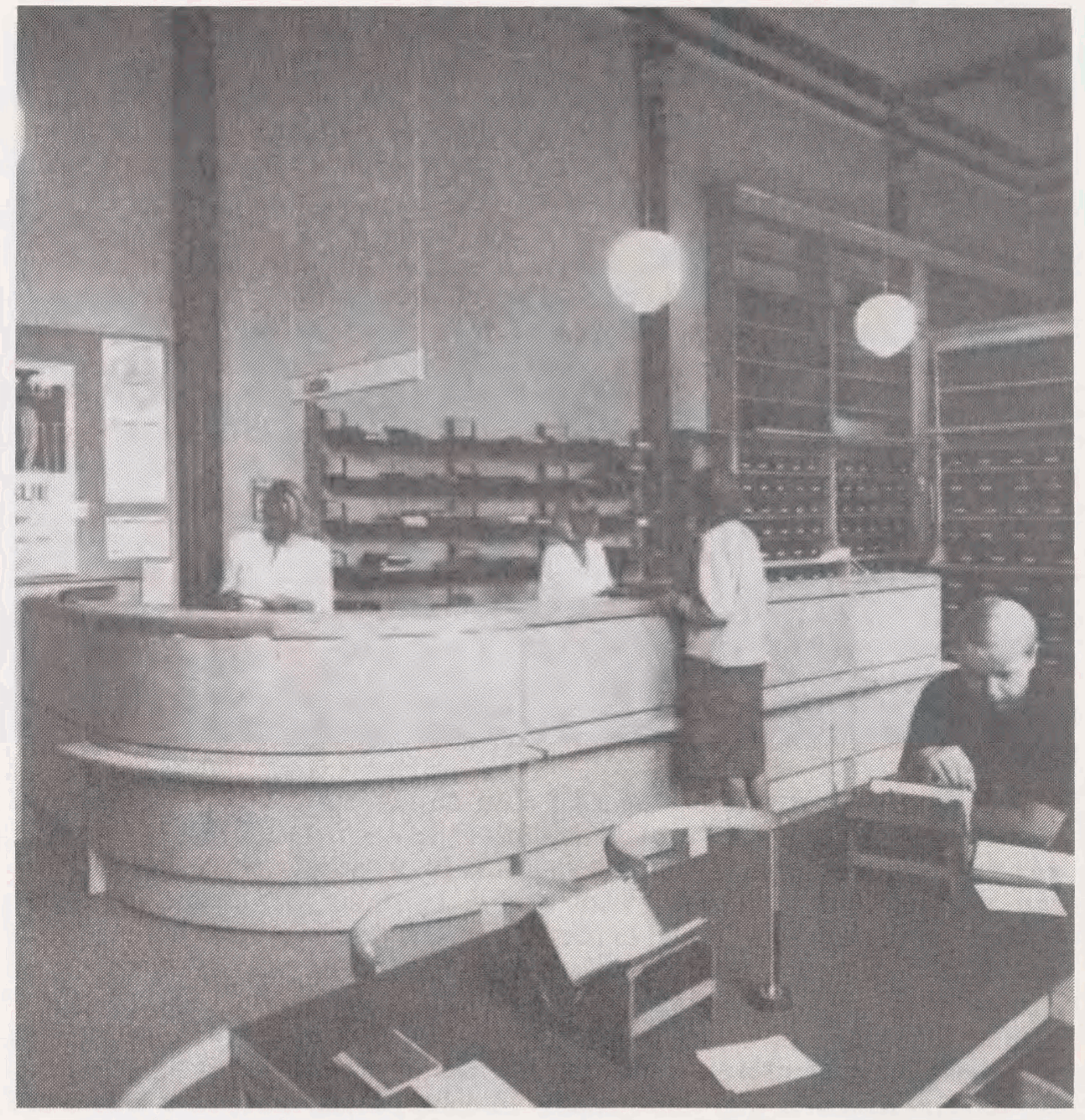

Det nye publikumslokale i Universitetsbiblioteket Fiolstræde. 


\title{
Rapport fra de fremskudte bastioner
} Nyt fra Universitetsbiblioteket Amager og Universitetsbiblioteket Fiolstræde

\author{
af førstebibliotekar Jørgen Thorning Sørensen
}

Det er snart nogle numre siden, at Universitetsbiblioteket Amager og Universitetsbiblioteket Fiolstræde har ladet høre fra sig i MAGASINs spalter. Dette skyldes ingenlunde dovenskab, men snarere det faktum, at vi i nærbibliotekerne siden sammenslutningen med Det kongelige Bibliotek har haft rigeligt op at gøre.

Det følgende skal derfor betragtes som en sammenfatning af væsentlige tildragelser i det sidste års tid. Jeg tør ikke love at kunne leve op til Torben Nielsens sproglige virtuositet, men forbeholder mig til gengæld ret til at forholde mig lige så frit til den givne disposition, som han havde for vane.

Torben Nielsen gik som bekendt af som overbibliotekar med udgangen af november 1988 og blev fejret med maner. Pr. 1. december blev Det kongelige Biblioteks planlægnings- og udviklingschef, førstebibliotekar Karl Krarup, konstitueret som overbiblioteker for det gamle Universitetsbibliotek afd. 1. (Sic!) Siden er konstitutionsperioden blevet noget længere, hvilket personalet $\mathrm{i}$ de to biblioteker har hilst velkomment. Ganske vist blev hans tiltræden vel i nogen udstrækning mødt med den naturlige skepsis, som møder alt nyt. Denne blev imidlertid hurtigt gjort til skamme, da der viste sig en meget høj grad af overensstemmelse mellem overbibliotekarens og vore gode ideer om, på hvilke områder fornyelse var påkrævet, hvorefter vi samdrægtigt kunne gå i gang med en tiltrængt modernisering.

I begge biblioteker skabtes således hurtigt via opstilling af terminaler i publikumsområderne adgang til on-line katalogen i REX, hvor hele Universitetsbiblioteket Amagers bogbestand og Universitetsbiblioteket Fiolstrædes accession ca. 1980 ff. nu er registreret. Dette har betydet en væsentlig forbedring af publikumsbetjeningen, også fordi Det kongelige Biblioteks nyere bogbestand nu via REX er søgbar på Universitetsbiblioteket Amager og Universitetsbiblioteket Fiolstræde. 
I Universitetsbiblioteket Fiolstræde gik man samtidig bort fra den hidtidige kortkatalog til fordel for on-line katalogisering direkte til REX, ligesom man ændrede det hidtidige klassifikationsprogram til DK 5, bl.a. ud fra den betragtning at en meget stor del af tilvæksten består af danske bøger, modtaget i kraft af rekvisitionsretten.

Samtidig gennemførtes i begge afdelinger fysiske ændringer af publikumsområderne, som har betydet bedre rammer for såvel publikum som personale. I Universitetsbiblioteket Fiolstræde har vi for små midler foretaget en ombygning af publikumsarealerne, som har bevirket, at den hidtidige opdeling i katalogværelse og udlån er erstattet af et arrangement, hvor disse funktioner nu virker som helhed $i$ et lyst og venligt rum med ny praktisk udlånsskranke og nyoprettet information.

På Universitetsbiblioteket Amager har man i udlånet taget Bibliotekscentralens fjernlånssystem i brug, hvilket har betydet en rationalisering af arbejdet og dermed en serviceforbedring hvad angår Universitetsbiblioteket Amagers meget store interurbanlån. Begge afdelinger er nu også i Forsknirgsbibliotekernes edb-kontors "postkasse", ligesom vi for ganske nylig har fået et telefax begge steder.

På Universitetsbiblioteket Amager har Apple opstillet et såkaldt Mac-lab med diverse PC'ere, laserprinter og scanner, hvilket har været en stor succes hos publikum.

Næste skridt i moderniseringsarbejdet var accessionens overgang til edb, som fandt sted i løbet af efteråret 1989. I denne forbindelse slog man accessions- og katalogiseringsafdelinger sammen til procesafdelinger, hvor disse arbejdsområder varetages af et team af medarbejdere i en og samme arbejdsgang. Dette fungerer nu, trods visse tekniske indkøringsvanskeligheder, tilfredsstillende i begge afdelinger.

I Universitetsbiblioteket Fiolstræde benytter man samtidig lejligheden til at omlægge rekvisitionen af danske bøger, som hidtidig havde været en selvstændig funktion. Denne er nu integreret i procesafdelingens arbejde og rekvisitionen foregår ved hjælp af de af Bibliotekscentralens poster, som lægges ind i REX. Også på dette felt har der dog været visse tekniske problemer.

Samtidig besluttede man i Universitetbiblioteket Amager at erstatte det hidtidige opstillingssystem med numerus-currens opstilling, hvilket bl.a. har den fordel, at det er pladsbesparende.

Alt i alt er integreringen af Universitetsbiblioteket Amager og Universitetsbiblioteket Fiolstræde i en ny og større sammenhæng således, synes vi selv, forløbet tilfredsstillende. Og nye interessante perspektiver tegner sig, ikke mindst i forbindelse med planerne om ombygning på Amager. 
Det bør endelig nævnes, at beslutningen om at overføre Dramatisk Bibliotek til Håndskriftafdelingen på Slotsholmen realiseres i løbet af foråret 1990, således at samlingerne efter sommerlukning i juli måned atter kan åbnes for publikum 1. august 1990. Katalogen vil da efter retrokonvertering være tilgængelig i REX.

Det kan ligeledes oplyses, at Det humanistiske Fakultets Specialbibliotek er ifærd med at blive overført til Universitetsbiblioteket Amager, hvor det vil være tilgængeligt for publikum fra 15 . august 1990 . Katalogen vil blive indlagt i REX, og samlingen vil efterhånden blive opstillet på åbne hylder og vil kunne hjemlånes efter Universitetsbiblioteket Amagers normale praksis.

\section{Erhvervelser}

Af særligt interessante erhvervelser kan nævnes, at begge biblioteker nu er gået ind i CD-Rom alderen, idet vi til Universitetsbiblioteket Amager har anskaffet MLA (Modern Language Association) og Psych-Lit og til Universitetsbiblioteket Fiolstræde Social Sciences Citation Index og Humanities Index.

\section{Udstillinger m.v.:}

Den 12, januar 1990 åbnede Universitetsbiblioteket Fiolstræde en udstilling af fotografen Tom Christoffersens billeder fra Sana i Nordyemen (se også omtalen andetssteds). Sammen med fotografierne udstilledes en del bøger, kort og museumsgenstande med tilknytning til Den arabiske Rejse 1761-67. Udstillingen var blevet til med velvillig bistand af forskningsbibliotekar Stig Rasmussen, Orientalsk Afdeling.

Den 16. oktober 1989 blev førstebibliotekar Jørgen Thorning Sørensen interviewet til Kanal 2's nyhedsudsendelse i forbindelse med avislæsesalens 50års jubilæum. 
